\title{
Pengaruh Sentuhan Spiritual Quantum terhadap Nyeri Saat Perubahan Posisi pada Pasien Paska Operasi di Ruang Perawatan Intensif
}

\author{
Ani Haryani' ${ }^{1}$ F Sri Susilaningsih ${ }^{2}$, Aat Sriati ${ }^{2}$ \\ ${ }^{1}$ STIKes Faletehan, ${ }^{2}$ Fakultas Keperawatan, Universitas Padjadjaran \\ Email: aat.sriati@gmail.com
}

\begin{abstract}
Abstrak
Pasien paska operasi besar berisiko mengalami komplikasi yang mengancam kehidupan. Mobilisasi dini merupakan salah satu prosedur untuk mencegah komplikasi tersebut, namun mobilisasi menyebabkan peningkatan nyeri. Sentuhan Spiritual Quantum (SSQ) merupakan intervensi komplementer berbasis biofield energy yang telah banyak digunakan pada praktik keperawatan untuk mengurangi nyeri post operasi. Tujuan penelitian ini adalah untuk mengetahui pengaruh SSQ terhadap nyeri saat miring kiri kanan pada pasien paska operasi. Desain penelitian adalah pre-eksperimental one group pretest-post test design. Jumlah sampel dalam penelitian adalah 18 orang yang didapat melalui purposive sampling. Intensitas nyeri diukur dengan menggunakan Numeric Rating Scale (0-10). Analisis data menggunakan wilcoxon test untuk mengetahui perbedaan intensitas nyeri pada pengukuran pre dan post test. Hasil penelitian menunjukkan nilai median intensitas nyeri saat istirahat adalah 5, posisi miring tanpa SSQ adalah 8, posisi miring setelah SSQ1 adalah 5,5 dan miring setelah SSQ 2 adalah 5. Terjadi penurunan yang bermakna saat miring setelah SSQ1 $(p=0,001)$ dan SSQ2. SSQ dapat menjadi alternatif bagi perawat di area keperawatan kritis dalam manajemen nyeri non farmakologis untuk meningkatkan kemampuan mobilisasi. Diperlukan penelitian lanjutan menggunakan sampel yang lebih besar dan kasus yang lebih bervariasi.
\end{abstract}

Kata kunci: Biofield, mobilisasi, nyeri paska operasi, sentuhan spiritual quantum.

\section{The Effect of Spiritual Quantum Touch towards Pain after Positioning among Post-Operative Patients in the Intensive Care Unit}

\begin{abstract}
Early mobilization is a common procedure to prevent post-surgical complications that may stimulate pain sensation among patients. Spiritual Quantum Touch (SSQ) is a bio field energy therapy which has been used to reduce post-operative pain. This study aimed to identify the effect of SSQ towards pain intensity during positioning (left and right prone). This quasi-experimental study recruited 18 subjects using purposive sampling technique. Pain intensity was measured using Numeric Rating Scale (0-10). Data was analysed using Wilcoxon test to identify the differences of pain intensity of pre and post measurement. It is shown that the pain intensity median during resting position was 5, prone position without SSQ were 8, and prone position after SSQ1 was 5, 5 , and prone position after SSQ2 was 5. There was a significant decrease after SSQ1 ( $=0,001)$ and SSQ2. Thus, nurses can use SSQ as an alternative of non-pharmacologic intervention to reduce post-operative pain in order to improve patient's mobility. Using larger samples and various types of cases is warrant for further research.
\end{abstract}

Keywords: Bio field, mobilization, post-operative pain, Spiritual Quantum Touch. 
Ani Haryani : Pengaruh Sentuhan Spiritual Quantum terhadap Nyeri saat Perubahan Posisi

\section{Pendahuluan}

Perkembangan teknologi kedokteran telah mendorong semakin meningkatnya prosedur operasi dalam menangani penyakit. Diperkirakan sekitar 234,2 juta prosedur operasi besar dilakukan setiap tahunnya di dunia dan diperkirakan sekitar 295 prosedur operasi pada setiap 100.000 penduduk (Weiser et al., 2008). Penggunaan obat-obat anestesi dan manipulasi organ tubuh yang lebih lama pada operasi besar menyebabkan proses pemulihan paska operasi juga lebih kompleks karena memengaruhi berbagai organ dan sistem tubuh (Smeltzer et al., 2010).

Risiko gangguan fungsi tubuh yang dapat mengancam kehidupan pada pasien paska operasi besar diantaranya atelektosis, pneumonia hipostatik, hipoksemia, masalah sirkulasi seperti atrial fibrilasi dan Deep Vein Thrombosiss (DVT). Risiko risiko tersebut juga diperberat dengan keadaan imobilisasi (Smeltzer et al., 2010; Johnson \& Meyenburg, 2009). Dengan demikian mobilisasi menjadi bagian penting dalam manajemen paska operasi untuk mencegah komplikasi. Secara umum mobilisasi dini meningkatkan fungsi seluruh organ tubuh. Mobilisasi memiliki efek yang signifikan dalam pemulihan dan mencegah terjadinya komplikasi paska operasi (Smeltzer et al., 2010).

Meskipun keuntungan mobilisasi dan efek merugikan imobilisasi pada pasien paska operasi telah banyak ditekankan dalam panduan perawatan pasien paska operasi, namun hal ini bukan berarti tanpa hambatan. Hasil penelitian pada 74 pasien ICU menunjukkan rerata waktu perubahan posisi adalah 7,7 jam (5-12 jam) dan hanya $2,7 \%$ pasien yang diposisikan setiap 2 jam. Kurangnya tenaga dan waktu perawat, hemodinamik yang tidak stabil, pasien yang tidak toleran dan nyeri menjadi hambatan dalam perubahan posisi sehingga tidak dapat dilakukan setiap dua jam (Krishnagopalan, Johnson, Low, \& Kaifman, 2002).

Hasil penelitian pada 5.957 pasien ICU menunjukkan bahwa perubahan posisi sebagai prosedur yang paling menyakitkan (mean 4,93; SD 3,09 skala 0-10) dibandingkan dengan prosedur melepas drain, perawatan luka, endotracheal suctioning, pemasangan Central Venous Catheter (CVC) dan Femoral Sheath removal (Puntillo et al., 2001).
Penelitian Dominique, Christophe, Alain dan Philippe (2008) pada 1680 pasien paska operasi juga menunjukkan bahwa $4,2 \%$ pasien paska operasi mengalami nyeri hebat pada saat istirahat dan meningkat menjadi $26,9 \%$ saat bergerak.

Berdasarkan identifikasi intensitas nyeri pada berbagai prosedur diatas, perubahan posisi/turning memiliki intensitas nyeri paling tinggi dibandingkan dengan prosedur lain, sehingga menjadi keadaan dilematis bagi perawat ICU dalam melakukan perubahan posisi sebagai awal dari proses mobilisasi dini. Tidak merubah posisi pasien untuk meningkatkan kenyamanan dapat meningkatkan risiko terjadinya komplikasi imobilisasi, sedangkan merubah posisi meningkatkan nyeri secara berulang.

Disisi lain, nyeri akut seperti nyeri pada saat perubahan posisi dapat mengaktifkan respon stres biologis dengan mengaktifkan sistem syaraf simpatis melalui pelepasan Corticotropin Releasing Factor oleh hipotalamus. Sebagai akibatnya adalah kadar epinefrin dan norepinefrin dalam tubuh menjadi meningkat. Hal ini menyebabkan peningkatan denyut jantung serta tekanan darah, memicu ketidakseimbangan suplai oksigen dengan kebutuhan dan penyembuhan luka yang kurang baik (Urden, Stacy, \& Lough, 2010; Sole, Klein \& Moseley, 2013).

Berdasarkan konsep tersebut maka peningkatan nyeri yang diakibatkan oleh perubahan posisi pada pasien paska operasi dapat menyebabkan perubahan hemodinamik. Dengan demikian perlu dilakukan upaya untuk mengurangi nyeri pada saat perubahan posisi agar posisi miring dapat dilakukan tanpa menyebabkan perubahan hemodinamik akibat meningkatnya intensitas nyeri.

Berdasarkan manajemen farmakologis untuk mengatasi nyeri post operasi, obat obatan yang biasa diberikan segera setelah operasi adalah opioid dan non-opioid. Barr et al., (2013) dalam manajemen nyeri, agitasi dan delirium merekomendasikan opioid sebagai obat pilihan kelas pertama untuk manajemen nyeri pada pasien kritis. Analgetik non opioid dapat diberikan untuk menurunkan jumlah pemberian opioid atau untuk menggantikan opioid sehingga menurunkan efek samping opioid. Yang Koo dan Eikermann (2011) menjelaskan 
Ani Haryani : Pengaruh Sentuhan Spiritual Quantum terhadap Nyeri saat Perubahan Posisi

efek samping opioid pada pasien kritis adalah depresi sistem pernafasan, sehingga penggunaan opioid dalam manajemen nyeri pasien kritis tetap memberikan konsekuensi kurang menguntungkan.

Jika memmerhatikan kembali definisi nyeri itu sendiri, dimana nyeri didefinisikan sebagai pengalaman sensori dan emosional yang tidak nyaman dihubungkan dengan kerusakan jaringan aktual atau potensial, maka keterlibatan emosi dalam nyeri tidak dapat dipisahkan (International Association for the study of Pain [IASP-Pain], 2011). Menurut Chapman (n.d), seorang peneliti di Utah University menjelaskan bahwa kuatnya keterkaitan nyeri dengan emosi dapat menjadi suatu peluang bagi tenaga kesehatan untuk dapat mengatasi nyeri dengan non farmakologis dimana salah satunya adalah melalui pendekatan psikologis. Pendekatanpendekatan psikologis menawarkan keuntungan yang lebih besar karena tidak memerlukan obat, alat, tidak menimbulkan efek samping dan dapat meningkatkan personal kontrol.

Berdasarkan penelusuran literatur pada databased elektronik yaitu CINAHL, MEDLINE, dan COCHRAN dengan menggunakan kata kunci biofield therapy, touch therapy, pain, postoperative, post surgery, acut pain yang dikombinasikan dengan intensive care atau critical care didapatkan terapi sentuhan seperti therapeutic touch dan healing touch merupakan salah satu intervensi non farmakologis dalam pelayanan keperawatan yang telah dikembangkan dari awal tahun 1970an untuk membantu mengatasi nyeri. Penelitian klinis menunjukkan terapi sentuhan menjadi evidence yang kuat dalam mengatasi nyeri kronis (Lindquist, Tracy, Savik, \& Watanuki, 2005; Morton \& Fontaine, 2009; Urden et al., 2010; Duennes, 2011).

Jain dan Mills (2009) melakukan systematic review pada 66 penelitian klinis dengan menggunakan terapi biofield dan hasilnya menunjukkan terapi biofield mampu menurunkan intensitas nyeri secara signifikan dan memperpanjang waktu permintaan terhadap analgetik pada pasien paska operasi dan luka bakar. Namun demikian, penelitian pemanfaatan terapi ini terhadap nyeri akut terutama dalam pelayanan di ICU masih sangat terbatas.
Biofield adalah energi yang mengelilingi tubuh, merupakan gelombang elektromagnetik. Biofield diyakini sebagai kesatuan dari kombinasi berbagai medan elektromagnetik ion-ion tubuh, molekul, sel, jaringan dan organ, membentuk gelombang yang kompleks. Gelombang ini dipercaya berperan dalam mengintegrasikan seluruh sistem tubuh. Pada penelitian-penelitian terdahulu, karena gelombang ini sangat lemah, ini dianggap sebagai energi buangan saja. Tetapi penelitian selanjutnya menemukan bahwa arus yang sangat kecil efektif dari pada arus besar dalam menstimulasi regenerasi jaringan (Feinstein \& Eden, 2008).

Energi listrik dalam tubuh dihasilkan dari perubahan muatan ion di dalam dan luar sel. Radiasi elektromagnetik merupakan gelombang yang menyebar sendiri. Walaupun energi elektromagnetik berjalan sebagai gelombang, tetapi dia dapat diserap oleh zat sebagai partikel yang disebut dengan foton. Foton terdistribusi sepanjang gelombang yang merambat. Menurut mekanika quantum, ketika sebuah elektron berpindah dari tingkat energi yang lebih tinggi ke tingkat energi yang lebih rendah, energi berupa sebuah partikel cahaya yang disebut foton akan dilepaskan. Sebagai contoh, kulit mengeluarkan sekitar 30 foton per sentimeter persegi per detik, bahkan pada lokasi tertentu, kulit menghasilkan osilasi elektrik yang sangat cepat, yaitu 1.600 putaran per detik. Aktivitas ini jauh lebih cepat dibandingkan dengan otak, otot dan jantung (Feinstein \& Eden, 2008).

Bagaimana efek biofield terapi terhadap pasien dibuktikan dalam penelititan pada 19 orang dewasa yang sehat. Hasil penelitian menunjukkan gelombang alfa meningkat secara signifikan pada sesi terapi dibandingkan dengan sesi plasebo. Peningkatan gelombang alfa terjadi setelah 4 menit terapi dan perbedaan yang signifikan dalam power values pada 5 menit dan 9 menit sesi terapi. Penelitian ini menyimpulkan bahwa terapi efektif dalam meningkatkan gelombang alfa pada area frontal dan sentral korteks serebri dibandingkan dengan sesi plasebo. Hasil penelitian ini dapat menjadi dasar proses fisiologis dari terapi biofield dalam menurunkan intensitas nyeri (Uchida et al., 2011).

Biofield energy menjadi sebagai gelombang yang sangat halus yang diterima oleh 
Ani Haryani : Pengaruh Sentuhan Spiritual Quantum terhadap Nyeri saat Perubahan Posisi

somatosensorik sebagai stimulus bukan nyeri yang mengaktifkan serabut syaraf sensoris berukuran besar, sehingga mengaktifkan inhibisi interneuron yang pada akhirnya akan menutup gerbang nyeri tersebut. Tertutupnya gerbang nyeri memperkuat transmisi biofield ke otak. Efek peningkatan biofield di otak adalah dengan merubah belombang beta pada otak menjadi gelombang alfa. Meningkatnya gelombang alfa didalam talamus merangsang pengeluaran beta endorfin dan dinorfin dari hipotalamus (Guyton \& Hall, 2008; Uchida et al., 2012).

DiIndonesia,terapisentuhyangberkembang adalah Sentuhan Spiritual Quantum (SSQ) yang merupakan pengembangan dari Quantum Touch di Amerika. Sentuhan Spiritual Quantum di definisikan sebagai seni penyembuhan dengan sentuhan tangan yang didasari cinta dan kasih sayang yang tulus, dilakukan dengan hati ikhlas disertai doa, sehingga memungkinkan penyembuhan itu terjadi (Benjamin, 2013).

Berdasarkan uraian dalam latar belakang inilah peneliti tertarik untuk melakukan penelitian klinis menggunakan terapi biofield yaitu Sentuhan Spiritual Quantum. Penelitian bertujuan untuk mengetahui pengaruh Sentuhan Spiritual Quantum terhadap intensitas nyeri saat perubahan posisi pada pasien paska operasi di ruang perawatan intensif melalui identifikasi intensitas nyeri saat istirahat, saat prosedur perubahan posisi miring tanpa intervensi SSQ, dan saat prosedur perubahan posisi setelah intervensi SSQ.

\section{Metode Penelitian}

Penelitian didesain menggunakan preeksperimental one group pretest- post test. Desain ini bertujuan untuk mengetahui pengaruh intervensi pada kelompok perlakuan dengan mengukur pre dan post test. Sejumlah 18 orang pasien dilibatkan dalam penellitian ( $\mathrm{Z} \alpha=5 \%$ dan $\mathrm{Z} \beta=80 \%$ ). Sampel didapatkan secara purposive, dengan kriteria: pasien dengan kesadaran kompos mentis, berusia antara 17-65 tahun, pasien dengan indikasi mobilisasi dan pasien dengan terapi analgetik intermitten 2-3 kali dalam 24 jam.

Penelitian dilaksanakan dari bulan Maret sampai dengan Juli 2014, dengan pengambilan data pada tanggal 10 Juni sampai dengan 19 Juli 2014. Penelitian dilaksanakan di ruang perawatan intensif RSUD Kabupaten Serang, meliputi ruang ICU (Intensive Care Unit) dan ruang HCU (High Care Unit). Prosedur dilakukan pada jam ke tiga setelah pemberian analgetik. Dilakukan pengukuran nyeri pada saat istirahat, lalu pasien dimiringkan dan dinilai nyeri saat dimiringkan. Pasien dikembalikan pada posisi terlentang dan dilakukan intervensi SSQ selama 20 menit lalu kembali dimiringkan dan dinilai intensitas nyeri nya. Intervensi kedua dilakukan setelah dua jam dari intervensi pertama dengan prosedur yang sama.

Nyeri saat perubahan posisi pada penelitian ini diukur dengan menggunakan Numeric rating Scale (NRS) yaitu skala nyeri secara subjektif dari pasien. NRS merupakan alat untuk menilai intensitas nyeri dengan menggunakan angka dalam rentang 0-10. Alat ini dipilih dengan pertimbangan telah banyak digunakan pada berbagai penelitian nyeri dan tidak terpengaruh oleh kendala perbedaan bahasa. NRS memiliki kesesuaian yang lebih baik pada 15 dari 19 penelitian dibandingkan dengan Visual Analogue Scale (Hjermstad et al., 2011). Cut off point yang digunakan adalah 1-3 sebagai nyeri ringan, 4-6 nyeri sedang dan 7-10 nyeri berat (Forchheimer et al., 2011) .

Data dikumpulkan melalui prosedur yang sama pada setiap sampel penelitian. Setiap pasien paska operasi yang telah sesuai dengan kriteria dan menyetujui untuk terlibat dalam penelitian dinilai intensitas nyeri saat istirahat dalam posisi terlentang, pasien dimiringkan untuk menilai intensitas nyeri saat perubahan posisi. Setelah didapatkan kedua nilai tersebut maka peneliti melakukan terapi SSQ selama 20 menit dan pasien kembali dimiringkan untuk dinilai intensitas nyeri saat perubahan posisi paska terapi. Pasien dipertahankan dalam posisi miring selama dua jam, setelah dua jam pasien kembali terlentang dan dilakukan terapi kembali selama 20 menit. Setelah terapi, pasien kembali dimiringkan untuk dinilai intensitas nyeri saat miring.

Sebelum dilakukan uji statistik, peneliti melakukan uji kenormalan data dengan menggunakan uji Shapiro Wilk. Uji ini dipilih karena berdasarkan penelitian sebelumnya menunjukkan bahwa Uji Shapiro 
Ani Haryani : Pengaruh Sentuhan Spiritual Quantum terhadap Nyeri saat Perubahan Posisi

Wilk memiliki power yang paling tinggi dibandingkan dengan kolmogoriv-Smirnov, Lilliefors maupun Anderson-Darling test (Razali \& Wah, 2011). Data yang dilakukan uji kenormalan adalah data nyeri saat miring sebagai nilai intensitas nyeri pre intervensi. Hasil uji kenormalan menunjukkan data tidak normal. Dilakukan modifikasi data dengan square root dan $\log 10$, dua modifikasi data variable intensitas nyeri saat miring masih memperlihatkan hasil Shapiro Wilk tidak lebih dari 0,05 oleh karena itu distribusi data diasumsikan tidak normal.

Analisis univariat pada penelitian ini menggunakan analisis deskriptif nilai median dan Inter Quartil Range (IQR). Analisis
Bivariat menggunakan uji non parametrik Wilcoxon test. Penilaian perbedaan intensitas nyeri pada pre dan post dengan menggunakan Wilcoxon test adalah dengan melihat nilai $p$ value. Jika $p$ value $<0,05$ maka hipotesis nol ditolak, dengan arti kata lain hipotesis alternatif diterima, berarti terdapat perbedaan yang bermakna antara intensitas nyeri saat perubahan posisi tanpa SSQ dengan menggunakan SSQ.

\section{Hasil Penelitian}

Karakteristik responden dan hasil pengukuran intensitas nyeri pada posisi telentang/ istirahat,

Tabel 1 Deskripsi Intensitas Nyeri pada Berbagai Posisi Berdasarkan Karakteristik Responden pada Pasien Paska Operasi di Ruang Perawatan Intensif $(n=18)$.

\begin{tabular}{|c|c|c|c|c|c|}
\hline \multirow[t]{2}{*}{ Karakteristik } & \multirow[t]{2}{*}{$\mathbf{f}(\%)$} & \multicolumn{4}{|c|}{ Intensitas Nyeri } \\
\hline & & $\begin{array}{l}\text { Terlentang/ } \\
\text { istirahat }\end{array}$ & $\begin{array}{c}\text { Miring tanpa } \\
\text { SSQ }\end{array}$ & $\begin{array}{l}\text { Miring dengan } \\
\text { SSQ1 }\end{array}$ & $\begin{array}{c}\text { Miring dengan } \\
\text { SSQ2 }\end{array}$ \\
\hline $\begin{array}{l}\text { Median } \\
\text { (IQR) }\end{array}$ & & $\begin{array}{c}5,00 \\
(3-6)\end{array}$ & $\begin{array}{c}8,00 \\
(6,5-10)\end{array}$ & $\begin{array}{c}5,50 \\
(5-7,25)\end{array}$ & $\begin{array}{c}5,00 \\
(4-6,25)\end{array}$ \\
\hline Jenis kelamin & & $0,238^{1}$ & $0,193^{1}$ & $0,168^{1}$ & $0,171^{1}$ \\
\hline Laki laki & $1(5,60)$ & & & & \\
\hline Perempuan & $17(94,40)$ & & & & \\
\hline Usia & & $0,045^{2}$ & $0,368^{2}$ & $0,344^{2}$ & $0,371^{2}$ \\
\hline 18-40 (Dewasa awal) & $15(83,30)$ & & & & \\
\hline 41-60 (dewasa tengah) & $2(11,10)$ & & & & \\
\hline >60 ( Dewasa akhir) & $1(5,60)$ & & & & \\
\hline Latar blakang budaya & & $0,609^{2}$ & $0,571^{2}$ & $0,497^{2}$ & $0,575^{2}$ \\
\hline Sunda & $9(50,00)$ & & & & \\
\hline Jawa & $7(38,90)$ & & & & \\
\hline Melayu & $2(11,10)$ & & & & \\
\hline Jenis tindakan operasi & & $0,182^{2}$ & $0,105^{2}$ & $0,083^{2}$ & $0,279^{2}$ \\
\hline Sectio & $9(50,00)$ & & & & \\
\hline Cholelithotomy & $5(27,80)$ & & & & \\
\hline Laparatomy & $2(11,10)$ & & & & \\
\hline Nefrectomy & $1(5,60)$ & & & & \\
\hline Appendictomy & $1(5,60)$ & & & & \\
\hline Jenis Anestesi & & $0,752^{1}$ & $0,582^{1}$ & $0,498^{1}$ & $0,893^{1}$ \\
\hline Umum & $9(50,00)$ & & & & \\
\hline Spinal & $9(50,00)$ & & & & \\
\hline Lama Perawatan & & $0,548^{2}$ & $0,837^{2}$ & $0,835^{2}$ & $0,545^{2}$ \\
\hline$<24$ jam & $5(27,80)$ & & & & \\
\hline 24-48 jam & $11(61,10)$ & & & & \\
\hline$>48$ jam & $2(11,10)$ & & & & \\
\hline Pemberian analgetik & & $0,503^{1}$ & $0,961^{1}$ & $0,702^{1}$ & $0,669^{1}$ \\
\hline
\end{tabular}


Ani Haryani : Pengaruh Sentuhan Spiritual Quantum terhadap Nyeri saat Perubahan Posisi

\begin{tabular}{|c|c|c|c|c|c|}
\hline \multirow[t]{2}{*}{ Karakteristik } & \multirow[t]{2}{*}{$\mathbf{f}(\%)$} & \multicolumn{4}{|c|}{ Intensitas Nyeri } \\
\hline & & $\begin{array}{c}\text { Terlentang/ } \\
\text { istirahat }\end{array}$ & $\begin{array}{c}\text { Miring tanpa } \\
\text { SSQ }\end{array}$ & $\begin{array}{l}\text { Miring dengan } \\
\text { SSQ1 }\end{array}$ & $\begin{array}{c}\text { Miring } \\
\text { dengan SSQ2 }\end{array}$ \\
\hline 8 jam & $6(33,3)$ & & & & \\
\hline $12 \mathrm{jam}$ & $12(66,7)$ & & & & \\
\hline Pengalaman operasi & & $0,768^{1}$ & $0,841^{1}$ & $0,767^{1}$ & $1,000^{1}$ \\
\hline 1 kali & $17(94,40)$ & & & & \\
\hline$>1$ kali & $1(5,60)$ & & & & \\
\hline
\end{tabular}

Grafik 1 Perbedaan Intensitas Nyeri Pasien Paska Operasi pada Posisi Istirahat, Miring Sebelum Intervensi SSQ dan Miring dengan Intervensi SSQ pada Pasien Paska Operasi di Ruang Perawatan Intensif $(n=18)$

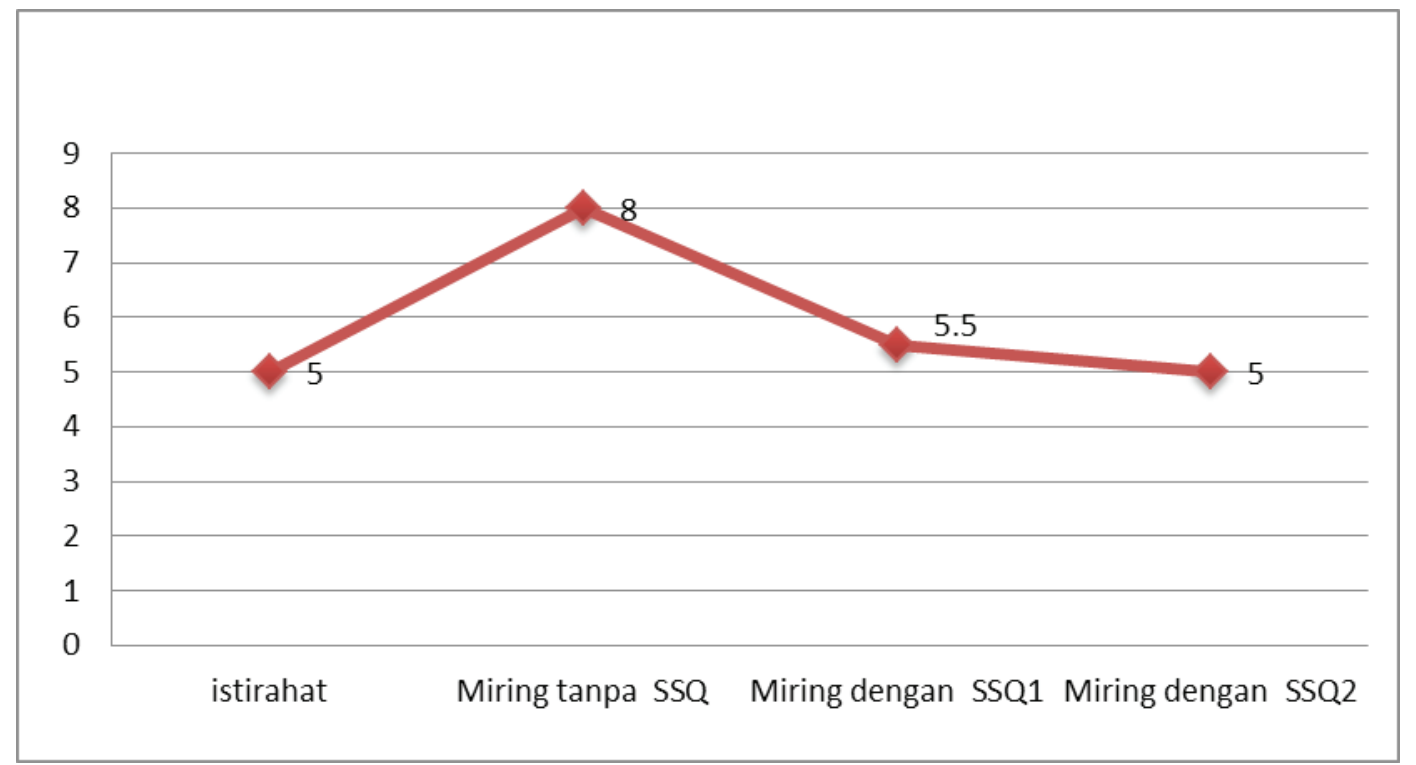

posisi miring tanpa intervensi SSQ dan posisi miring setelah intervensi SSQ dirangkum dalam tabel 1. Hampir seluruh responden $(94,40 \%)$ adalah perempuan. Sebagian besar $(83,3 \%)$ dari responden berada pada usia dewasa awal yaitu antara usia 18-40 tahun dan setengah dari responden berasal dari latar belakang budaya sunda. Setengah dari responden merupakan pasien dengan post sectio caesaria $(50 \%)$, jenis anestesi yang digunakan adalah anestesi umum dan spinal dan sebagian besar mendapatkan program pemberian analgetik setiap 12 jam. Berdasarkan lama hari perawatan paska operasi sebagian besar responden merupakan pasien yang telah dirawat selama 24-48 jam dari tindakan operasi. Hampir seluruh responden merupakan pasien dengan pengalaman pertama menjalani operasi.

Intensitas nyeri tidak berbeda secara bermakna pada berbagai posisi pengukuran berdasarkan karakteristik responden ( $\mathrm{p}$ value $>0,05)$, sehingga dapat disimpulkan bahwa perbedaan intensitas nyeri setelah intervensi SSQ menggambarkan efek dari intervensi tersebut dan tidak dipengaruhi oleh perbedaan karakteristik yang melekat pada pasien.

Perubahan intensitas nyeri pada posisi miring sebelum dan sesudah intervensi SSQ ditunjukkan dalam grafik 1. Berdasarkan nilai median, intensitas nyeri pada saat terlentang/ istirahat adalah 5 . Terjadi peningkatan intensitas nyeri yang bermakna $(p=0,000)$ dari posisi istirahat ke posisi miring sebesar 3 skala nyeri menjadi 8 . Pada penilaian intensitas nyeri saat posisi miring setelah intervensi SSQ 
Ani Haryani : Pengaruh Sentuhan Spiritual Quantum terhadap Nyeri saat Perubahan Posisi

sesi 1 didapatkan penurunan intensitas nyeri secara bermakna $(p=0,001)$ sebesar 2,5 skala nyeri menjadi 5,5. Pada penilaian intensitas nyeri setelah intervensi SSQ sesi 2 juga didapatkan penurunan intensitas nyeri sebesar 0,5 sehingga intensitas nyeri kembali pada nilai saat istirahat yaitu $5(p=0,041)$.

\section{Pembahasan}

Hasil pada penelitian menunjukkan bahwa intensitas nyeri pada pasien paska operasi saat istirahat adalah 5 dan meningkat menjadi 8 pada posisi miring. Nilai intensitas nyeri pada penelitian ini lebih tinggi dibandingkan hasil penelitian Dominique et al., (2008) yang mengidentifikasi rata rata nyeri pasien paska operasi pada 24 jam pertama adalah 2,7 saat istirahat dan 4,9 saat bergerak. Perbedaan ini disebabkan oleh perbedaan waktu penilaian, dimana dalam penelitian ini nyeri di nilai pada tiga jam setelah jadwal pemberian analgetik dimana efek puncak analgetik telah berkurang. Pada penelitian Dominique penilaian nyeri dilakukan secara berkala selama 24 jam dengan pemberian analgetik sesuai program.

Perbedaan waktu pengukuran nyeri dalam rentang pemberian analgetik akan sangat memengaruhi nilai intensitas nyeri. Pasien dengan pemberian titrasi opiod maupun analgetik non opioid akan tetap mendapatkan manfaat analgesia, sehingga intensitas nyeri yang dirasakan akan berkurang. Pengukuran intensitas nyeri pada penelitian ini adalah 3 jam setelah pemberian analgetik terakhir. Waktu ini, merupakan waktu yang telah melewati masa efek puncak dari analgetik yang diberikan, dimana ketorolac $30 \mathrm{mg}$ memberikan efek puncak pada 1-2 jam paska pemberian.

Intensitas nyeri pada penelitian ini juga lebih tinggi jika dibandingkan dengan hasil penelitian Gerbershagen et al., (2013) yang dilakukan pada 70.518 pasien paska operasi dengan berbagai jenis tindakan operasi baik minor maupun mayor di Jerman. Hasil penelitian menyebutkan bahwa nilai median intensitas nyeri saat perubahan posisi adalah 4. Hasil penelitian Juga mengidentifikasi bahwa intensitas nyeri dirasakan lebih tinggi pada pasien dengan tindakan operasi sedang. Hal ini disebabkan karena penatalaksanaan opioid pada operasi besar lebih baik daripada operasi sedang.

Selama proses penelitian, peneliti mengamati penggunaan opioid dalam tatalaksana nyeri pasien paska operasi di ruang perawatan intensif RSUD Kabupaten Serang. Sebagian besar responden mendapatkan analgetik non opioid setelah keluar dari ruang pemulihan. Selesai pemberian analgetik non opioid titrasi, program analgetik dilanjutkan dengan pemberian analgetik non opioid setiap 8 jam atau 12 jam. Sebagain besar responden mendapatkan program analgetik setiap 12 jam. Alasan yang menjadi dasar dari dokter penanggung jawab dengan pemilihan ini adalah dengan tujuan meminimalkan efek samping analgetik terhadap fungsi ginjal. Pemberian analgetik tambahan hanya diberikan jika nyeri menyebabkan perubahan hemodinamik secara signifikan.

Sebagain besar pasien pada penelitian ini mendapatkan program analgetik 12 jam, maka pasien berpotensi untuk mengalami nyeri sedang sampai berat pada 10 jam sebelum jadwal pemberian analgetik berikutnya. Hal lain yang menunjang potensi ini adalah tidak adanya evaluasi intensitas nyeri secara berkala dari perawat maupun dokter. Dalam lembar monitoring yang didokumentasikan setiap jam dalam asuhan pada pasien adalah niali nilai hemodinamik, intake-output dan program terapi. Dengan demikian nyeri semakin tidak menjadi perhatian dalam proses asuhan keperawatan.

Nyeri akut persisten pada pasien paska operas akan berisiko menyebabkan terjadinya nyeri kronis paska operasi dan berhubungan secara signifikan dengan keterlambatan penyembuhan luka. Dengan demikian maka pasien berisiko untuk mengalami nyeri kronis maupun keterlambatan dalam proses pemulihan (Lamacraft, 2012; McGuire et al., 2010).

Berdasarkan penilaian intensitas nyeri pada posisi miring tanpa intervensi SSQ, hasil penelitian menunjukkan terjadi peningkatan intensitas nyeri dari kategori sedang ke kategori berat. Hasil penelitian ini sesuai dengan hasil penelitian Puntillo et al. (2001) yang juga menunjukkan perubahan posisi sebagai prosedur yang menyakitkan. Peningkatan intensitas nyeri pada posisi miring ini juga akan berpotensi adanya hambatan dalam 
Ani Haryani : Pengaruh Sentuhan Spiritual Quantum terhadap Nyeri saat Perubahan Posisi

prosedur mobilisasi dini. Secara konsep telah dijelaskan bahwa intensitas nyeri berat dapat memicu respon stress sehingga menyebabkan terganggunya hemodinamik pasien. Selain memengaruhi hemodinamik, peningkatan nyeri juga dapat memengaruhi emosi pasien sehingga pasien dapat mengalami distress emosional (Chapman, n.d).

Berbeda dengan hasil penilaian pada posisi miring tanpa SSQ, hasil penilaian pada posisi miring setelah dilakukan intervensi SSQ sesil lebih rendah dan berbeda secara bermakna. Demikian pula pada pengukuran ke tiga yaitu miring dengan intervensi SSQ sesi 2 juga terjadi penurunan intensitas nyeri yang signifikan, sehingga intensitas nyeri pada penilaian setelah intervensi SSQ sesi 2 kembali pada nilai awal saat istirahat.

Hasil penelitian ini mendukung hasil penelitian sebelumnya yang membuktikan terapibiofield sebagai intervensi komplementer mampu menurunkan nyeri pada pasien paska operasi. Dengan demikian, penelitian juga membuktikan bahwa terapi sentuhan dengan menggunakan dasar biofield energy mampu menurunkan intensitas nyeri yang bersifat akut seperti nyeri pada pasien paska operasi hari pertama sampai dengan hari ke dua (Hardwik, Pulido \& Anderson, 2012; Coackley \& Duffy, 2012; McCormack, 2009).

Penurunan intensitas nyeri setelah intervensi SSQ dapat dipengaruhi oleh pendekatan emosional dan spiritual yang ada pada prosedur SSQ. Pendekatan emosional dilakukan dengan mengembangkan komunikasi untuk membangun hubungan saling percaya sebelum melakukan terapi sehingga pasien dengan kesadarannya bersedia mengikuti terapi. Pendekatan spiritual dibangun dengan mengajak pasien berdoa agar dibebaskan dari rasa sakit dan segera pulih.

Kedua langkah dalam prosedur SSQ ini dapat memfasilitasi pendekatan emosional dan spiritual dalam mengatasi nyeri, selain aspek biofield energy. Intervensi-intervenai keperawatan yang dapat mengatasi masalah psikologis pada pasien adalah dengan meningkatkan hubungan saling percaya dan menghadirkan diri/being there (Morton, 2009). Selain itu, dalam hubungan perawat pasien, sentuhan memiliki makna perhatian dan kedekatan yang memediasi empati sehingga meningkatkan hubungan antara perawat-pasien yaitu hubungan saling percaya ternyata memberikan kepuasan pada pasien, memfasilitasi pasien untuk merasa damai, aman dan ringan dalam menghadapi penderitaan. Hubungan saling percaya juga memungkinkan perawat untuk dapat meminimalkan distress pada prosedur prosedur yang menyebabkan nyeri (Vouzavali et al, 2011; Dinc \& Gastmas, 2013).

Secara klinis hasil dari penelitian ini sangat bermanfaat bagi pasien paska operasi, dimana pada saat pasien mendapatkan terapi analgetik 8 dan 12 jam, SSQ bisa menjadi alternatif manajemen nyeri non farmakologis pada 6 dan 10 jam berikutnya saat efek analgetik mulai berkurang. SSQ sangat membantu pada tahap awal intervensi mobilisasi. Peneliti melakukan wawancara kepada lima orang responden yang mengalami progres yang baik dalam kemampuan mobilisasi untuk mendapatkan data tambahan. Responden mengungkapkan bahwa intervensi SSQ sangat membantu meningkatkan kemampuan mobilisasi mereka, karena menurut responden yang paling sulit untuk mobilisasi adalah saat memulai, karena nyeri yang dirasakan sangat kuat, tetapi setelah sering digerakkan lama kelamaan nyeri akan semakin berkurang. Dengan demikian SSQ memiliki peran penting dalam menunjang keberhasilan program mobilisasi dini pada pasien paska operasi.

Selain efek menurunnya intensitas nyeri pada pasien paska operasi, beberapa keuntungan lain yang dilaporkan oleh responden adalah merasakan nyaman, hangat yang menyebar dirasakan dari sentuhan tangan terapis. Responden lain melaporkan merasakan seperti adanya aliran listrik yang rendah yang membuat rileks dan merasakan tenang. Sepuluh dari delapan belas responden (56\%) melaporkan menjadi lebih nyenyak tidur setelah menjalani terapi. Dua orang responden melaporkan menjadi tidak sakit pada saat flatus. Berdasarkan pengamatan selama proses terapi, sebagian besar responden (67\%) tertidur selama proses terapi bahkan pada responden yang melaporkan nyeri dengan intensitas sangat tinggi (9-10).

Berdasarkan analisis karakteristik responden terhadap intensitas nyeri, terdapat beberapa persamaan dan juga perbedaan hasil jika dibandingkan dengan penelitian sebelumnya. Berdasarkan jenis kelamin, 
Ani Haryani : Pengaruh Sentuhan Spiritual Quantum terhadap Nyeri saat Perubahan Posisi

hasil penelitian menunjukkan hampir seluruh responden berjenis kelamin perempuan. Hal ini dipengaruhi oleh jenis kasus yang ditemui, dimana sebagian besar kasus merupakan kasus obstetri dan ginekologis yang seluruhnya terjadi pada perempuan.

Berdasarkan latar belakang budaya, hasil penelitian ini tidak sesuai dengan hasil penelitian sebelumnya yang menunjukkan bahwa terdapat perbedaan intensitas nyeri pada latar belakang budaya yang berbeda. Perbedaan hasil penelitian ini disebabkan karena budaya sunda, jawa, dan melayu yang menjadi bagian dari masyarakat Banten telah mengalami akulturasi, sehingga identitas budaya pada responden tidak lagi melekat dengan kuat dan memengaruhi intensitas nyeri. Selain itu, kedua penelitian terdahulu membandingkan etnis yang benar benar berbeda secara ras, sedangkan pada penelitian ini ketiga etnis masih dalam satu rumpun yaitu rumpun melayu (Vlaar et al., 2007; Richardson, 2012).

Berdasarkan usia, didapatkan hasil bahwa terdapat perbedaan intensitas nyeri pada saat istirahat. Hasil penelitian ini sejalan dengan hasil penelitian sebelumnyayang menunjukkan hasil bahwa intensitas nyeri paska operasi lebih rendah pada usia tua dibandingkan dengan kelompok usia muda (Gagliese \& Katz, 2003; Li et al., 2008). Tingginya intensitas nyeri pada penelitian ini juga dapat dipengaruhi dari jumlah responden yang sebagian besar berada pada usia dewasa awal. Adanya pengaruh usia terhadap intensitas nyeri juga dapat disebabkan oleh keadaan emosional, dimana sebagian besar responden merupakan responden dengan usia dewasa awal. Sesuai dengan karakteristik perkembangannya, pada masa ini memiliki kecenderungan mengalami keresahan emosional akibat tanggung jawab yang besar.

Berdasarkan jenis tindakan operasi, sebagian responden merupakan pasien dengan sectio. Sesuai dengan data tahunan jumlah pembedahan berdasarkan SMF tahun 2012 di RSUD Kabupaten Serang, kasus obstetri ginekologi merupakan kasus tertinggi yaitu sejumlah 1352 kasus. Dari seluruh kasus tersebut, sebagian besar merupakan pembedahan mayor dengan kasus darurat sejumlah 326 kasus. Hampir seluruh dari kasus ini memerlukan perawatan intensif baik di ruang ICU maupun ruang HCU. Berdasarkan sepuluh penyakit terbesar kunjungan rawat inap pasien Jamkesmas pada tahun 2012 juga diketahui bahwa prosentase tertinggi adalah kasus ketuban pecah dini dan pre eklamsi berat yang pada akhirnya banyak diikuti dengan tindakan pembedahan yaitu sectio caesaria. Delapan dari sembilan responden dengan sectio pada penelitian ini merupakan pasien dengan preeklamsi berat.

Hasil analisis menunjukkan bahwa tidak ada perbedaan intensitas nyeri pada responden berdasarkan jenis tindakan operasi. Hasil penelitian ini sejalan dengan hasil penelitian sebelumnya yang mengungkapkan bahwa luasnya luka operasi yang disebabkan berbagai jenis tindakan operasi tidak berhubungan dengan intensitas nyeri paska operasi (Gerbershagen et al., 2013).

Berdasarkan lama perawatan paska operasi, sebagian besar responden berada pada masa perawatan 24-48 jam paska operasi. Hasil analisis intensitas nyeri berdasarkan lama hari perawatan paska operasi didapatkan tidak ada perbedaan. Hasil penelitian ini sesuai dengan hasil penelitian McGuire et al. (2006) pada 17 wanita dengan pembedahan elektif gastric bypass yang diikuti selama lima minggu. Hasil penelitian menunjukkan bahwa intensitas nyeri paling tinggi terjadi pada hari pertama dan ke dua paska operasi.

Berdasarkan jenis anestesi yang digunakan, responden dalam penelitian ini terbagi kedalam dua kelompok yang sama besar antara yang menggunakan anestesi umum dengan anestesi spinal. Hasil analisis menunjukkan tidak ada perbedaan intensitas nyeri pada berbagai posisi pada kedua kelompok penggunaan anestesi ini. Hasil penelitian ini mendukung hasil penelitian sebelumnya yang menunjukkan skor nyeri pada kedua kelompok hampir seimbang, sehingga tidak terdapat perbedaan intensitas nyeri pada 6 sampai dengan 24 jam paska operasi (Kessous et al., 2012; Naghibi, Saryazdi, Kashefi \& Rohani, 2013).

\section{Simpulan}

Berdasarkan hasil penelitian ini dapat disimpulkan bahwa intensitas nyeri pada pasien paska operasi saat istirahat setelah tiga jam pemberian analgetik adalah nyeri 
Ani Haryani : Pengaruh Sentuhan Spiritual Quantum terhadap Nyeri saat Perubahan Posisi

sedang dan meningkat menjadi nyeri berat dengan adanya prosedur miring kiri dan kanan sebagai awal proses mobilisasi. SSQ sebagai intervensi komplementer berbasis biofield energy terbukti mampu menurunkan intensitas nyeri saat miring kiri dan kanan pada masa efek analgetik yang telah berkurang, sehingga mobilisasi miring kiri dan kanan tetap dapat dilakukan dengan aman. Intervensi ini juga memberika keuntungan lain seperti meningkatnya kualitas tidur dan kenyamanan pada pasien.

\section{Daftar Pustaka}

Barr, J., Fraser, G.L., Puntillo, K., Ely, E.W., Gélinas, C., Dasta, J.F., et al. (2013). Practice guidelines for the management of pain, agitation, and delirium in adult patients in the Intensive Care Unit. Critical Care Medicine Journal.

Benjamin, R.S. (2013). Modul workshop sentuhan spiritual quantum. Jakarta. 1-2 Juni 2013.

Chapman, C.R. (n.d). The emotional aspect of pain. Melalui http://www.painresearch.utah. edu. $(10 / 7 / 13)$.

Coakley, A.B., \& Duffy, M.E. (2010). The effect of therapeutic touch on postoperative patients.

Dinc, L., \& Gastmas, C. (2013). Trust in nurse-patient relationship: A literatur review. Nursing Ethics, 20(5), 501-516.

Dominique, F., Christophe, F., Alain, M., \& Philippe, A. (2008). A patient-based survey on postoperative pain management in France reveals significant achievements and persistent challenges. Author manuskrip, Published in Journal Pain, 137(2), 441-51. DOI: 10.1016/j. pain.2008.02.026.

Duennes, M. (2011). Florence Nightingale, healing touch and the year of the nurse. Energy magazine, 48.

Feinstein, D., \& Eden, D. (2008). Six pillars of energy medicine: Clinical strengths of a complementary paradigm. Alternative Therapies in health and Medicine, 14(1). ProQuest Research Library (10/6/13).

Forchheimer, M.B., Richards, J.S., Chiodo, A.E., Bryce, T.N., \& Dyson-Hudson, T.A. (2011). Cut point determination in thement of pain and its measurement of pain and its relationship to psychosocial and functional measures after traumatic spinal cord injury: A retrospective model spinal cord injury analysis. Archives of Physical medicine and rehabilitation.

Gagliese \& Katz. (2003). Age differences in postoperative pain scale dependent: $A$ comparison of measures of pain intensity and quality in younger and oleder surgical patients.

Gerbershagen, H.J., Aduckathil, S., Van Wijck, A., Peelen, L.M., Kalkman, M.D., \& Meissner, W. (2013). Pain intensity on the first day after surgery: A prospective cohort study comparing 179 surgical procedures. The Journal of the American Society of Anesthesiologists, 118(4), 934-44.

Guyton, A.C., \& Hall, J.E. (2008). Buku ajar fisiologi kedokteran (Ed. 11). Alih bahasa: Irawati dkk. Jakarta: EGC.

Hardwick, M.E., Pulido, P.A., \& Adelson, W.S. (2012). Nursing intervention using healing touch in bilateral total knee arthroplasty. Orthopaedic Nursing, 31(1). ProQuest Research library pg. 5.

Hjermstad, M.J., Feyers, P.M., Haugen, D.F., Caraceni, A., Hanks, G.W., \& Loge, J.H. (2011). Studies comparing numerical rating scales, verbal rating scales, and visual analogue scales for assessment of pain intensity in adults: A systematic literatur review. Journal of pain and symptom management, 41(6).

International Association for the study of Pain (IASP). (2011). IASP Taxonomy.

Jain, S., \& Mills, P.J. (2010). Biofield therapies: Helpful or full of hype? A best evidence synthesis. International Journals Behavior Medicine, 17, 1-16. 
Ani Haryani : Pengaruh Sentuhan Spiritual Quantum terhadap Nyeri saat Perubahan Posisi

Johnson, K.L., \& Meyenburg, T. (2009). Physiological rationale and current evidence for therapeutic positioning of critically ill patients. AACN Advanced Critical Care, 20(3), pp.228-240 in the Public Domain.

Kessous, R., Weintraub, A.Y., Wiznitzer, A., Zlotnik, A., Pariente, G., Polachek, H., ..., Sheiner, W. (2012). Spinal versus general anesthesia in cesarean sections: The effects on postoperative pain perception (Abstrak). Archives of Gynecology and Obstetrics, 286(1), pp 75-79.

Krishnagopalan, S., Johnson, W., Low, L.L., \& Kaifman, L.J. (2002). Body positioning of intensive carre patients: Clinical practice versus standards. Critical Care Medicine, $30(11)$.

Lamacraft, G. (2012). The link between acute postoperative pain and chronic pain syndromes. South Africa Journal Anaesthesy Analgesi, 18(1), 45-50.

Li, S.F., Greenwald, P.W., Gennis, P., Bijur, P.E., \& Gallaqher, E.J. (2001). Effect of age on acute pain perception of a standardized stimulus in the emergency department (Abstract). Annals of emergency medicine, 38(6), pages 644-647.

Linquist, L., Tracy, M.N., Savik, K., \& Watanuki, S. (2005). Regional use of complementary and alternative therapies by critical care nurses. Critical Care Nurse Journal.

McCormack. (2009). Using non-contact therapeutic touch to manage post-surgical pain in the eldery (Abstract). Occupational therapy International, 16(1), 44-56. doi:10.1002/ oti.264.

McGuire, L., Heffner, K., Glaser, R., Needleman, B., Malarkey, W., Dickinson, S., ... Kiecolt-Glaser, J.K. (2006). Pain and wound healing in surgical patients. Ann Behavior Medicine, 31(2), 165-72.

Morton, P.G., \& Fontaine, D.K. (2009). Critical care nursing: A holistic approach (9th Ed.). Lippincott Williams \& Wilkins.
Naghibi, K., Saryazdi, H., Kashefi, P., \& Rohani, F. (2013). The comparison of spinal anesthesia with general anesthesia on the postoperative pain scores and analgesic requirements after elective lower abdominal surgery: A randomized, double-blinded study. Journal of Research in Medical Science, 18(7), 543-548.

Puntillo, K.A., White, C., Morris, A.B., Perdue, S.D., Stanik-Hutt, J., Thompson, C.L. et al. (2001). Patients perceptions and responses to procedural pain: Results from Thunder Project II. American Journal of Critical care, 10(4).

Razali, N.M., \& Wah, Y.B. (2011). Power comparisons of Shapiro-Wilk, KolmogorovSmirnov, Lilliefors, and Anderson-Darling Test. Journal of Statistical Modeling and Analytics, 2(1), 21-33.

Richardson, G. (2012). Pain expression in different cultures. A qualitative study of the analysis for the cues of pain in different cultures (Thesis degree for bachelor of health care). NOVIA university of applied Science.

Smeltzer, S.C., Bare, B.G., Hinkle, J.L., \& Cheever, K.H. (2010). Textbook of medical surgical nursing (12th Ed.). Philadelpia: Lippincott Williams.

Sole, M.L., Klein, D.G., \& Moseley, M.J. (2013). Introduction to critical care nursing (6th Ed.). Missouri. Elsevier.

Uchida, S., Iha, T., Yamaoko, K., Nittia, K., \& Sugano, H. (2011). Effect of biofield therapy in the human brain. The Journal of alternative and complementary medicine, 18(9), pp.875879. DOI:10.1089/acm.2011.0428.

Urden, L.D., Stacy, K.M., \& Lough. M.E. (2010). Critical care nursing: Diagnosis and management. Canada: Mosby Elsevier.

Vlaar, A.P.J., ten Klooster, P.M., Taal, E., Gheith, R.E., El-Garf, A., Rasker, J., ..., de Laar, V. (2007). A cross-cultural study of pain intensity in Egyptian and Dutch woman with rheumatoid arthritis. The Journal of Pain, 8(9), pp 730-738. 
Ani Haryani : Pengaruh Sentuhan Spiritual Quantum terhadap Nyeri saat Perubahan Posisi

Vouzavali, F., Papathanassoglou, E., A.A., (2008). An estimation of the global Karanikola, M., Koutroubas, A., Patiraki, volume of surgery: A modelling strategy based E., \& Papadatou, D. (2011). The patient is on available data. Lancet, 372, 139-44. DOI: my space: Hermeneutic investigation of the 10.1016/S0140-6736(08)60878-8.

nurse-patient relationship in critical care. British Association of Critical Care Nurses, 16(3).

Weiser, T.G., Regenbogen, S.E., Thompson,

Yang Koo, C., \& Eikermann, M. (2011).

Respiratory effects of opioid in perioperative medicine. The Open Anesthesiology Journal, K.D., Hayners, A.B., Berry, W.R., \& Gawande, 